\title{
Notes and News
}

\section{Lord Lugard}

Aт a meeting of the Bureau of the Institute on 26 March Lord Lugard announced that he must resign the chairmanship because he felt that he no longer had the physical and mental energy to carry out the duties of the office. Needless to say, this decision, though not unexpected seeing that Lord Lugard had entered his 88th year, was accepted with the most profound regret by the Bureau. A few days later he was stricken fatally and on II April his gallant spirit took its flight.

In this number we have not been able to include tributes to his memory from members of the Institute who reside outside Britain; but we are confident that they will wish to associate themselves with the tributes which we have printed.

\section{The New Chairman: Lord Hailey}

WE are happy to say that at the meeting of the Bureau on 26 March, Lord Hailey consented to step for a limited period into the breach created by Lord Lugard's retirement. He was appointed Chairman by the Bureau. There is no need to expend many words in introducing Lord Hailey to our readers. After a long and distinguished career in India culminating in the Governorship of the United Provinces, he undertook to direct for Lord Lothian's committee the Survey of Africa south of the Sahara the published record of which has been universally acclaimed as (in Lord Lothian's words) 'a clear and objective study of significant facts on a scale and of a quality never previously available'. Subsequent travels over large parts of Africa have given him a still wider knowledge of conditions and a deeper insight into the problems. It is not too much to say that Lord Hailey has inaugurated a new era in African colonial policy. He is a convinced exponent of the views in regard to the vital necessity of research upon which the Institute was founded. All his ripe experience in the conduct and direction of investigations will be of the utmost value in promoting international co-operation in this field. In these days of expanding horizons we confidently look to him to lead the Institute in fresh tasks and wider successes.

\section{Some Other Items of Business}

THE Bureau examined and adopted the budget for 1945. This shows a small anticipated deficit. Generous subscriptions have been received from, or are promised by, the Belgian, British, French, and Portuguese colonial governments, and by the Union of South Africa. There has been a pleasing increase in the membership. The present subscription of $\oint_{1} \mathbf{I}$ barely covers the cost of the copies of Africa which members receive; and the Bureau considered it to be necessary slightly to raise the annual subscription to 25 shillings, from I January 1946 . Among the publications which may be expected during this year are the first volume of Dr. Fortes's Dynamics of Clanship, the fruit of his research as a Fellow among the Tallensi, and Dr. Hilda Kuper's book on the Swazi entitled An African Aristocracy. The Bureau confirmed the appointment of Mrs. Wyatt as secretary of the Institute and of Edwin W. Smith as editor of Africa.

Under war conditions it has been impossible to bring together all the members of the Executive Council. It is now hoped that by the end of the year it will be possible to resume the meetings of this international board.

\section{The Conference of Africanists at Dakar}

THE Bureau received from the Director of the Institute, Professor Daryll Forde, an account of the Dakar Conference-Première Réunion des Ethnographes, Géographes et Naturalistes 